\title{
ДОСЛІДЖЕННЯ ВПЛИВУ РЕЖИМІВ САНІТАРНО-ГІГІЄНІЧНОЇ ОБРОБКИ ПАВІЛЬЙОНУ ДЛЯ УТРИМАННЯ СОБАК
}

\section{Т. Пушкар, С. Гурко, К. Хамід}

Одеський державний аграрний університет

\begin{abstract}
Проведено дослідження щуодо санітарної обробки приміщення для утримання собак різними дезінфектантами. Показано перспективність озонових технологій для дезінфекиії павільйону.

Санітарна обробка вольєру здійснювалась за допомогою гарячого розчину «Хлорантоін» (дезінфекційний засіб з миючим ефектом ). При оцінці початкового санітарного стану примімення для утримання собак установлено, щуо забрудненість майже всіх ділянок перевищувала допустиму норму.

Доведено, щуо озоно-повітряна суміш є ефективним способом знезараження примішення та дезінфекиії повітря, ступінь якого залежить від конщентраиії озону і тривалості експозииії.

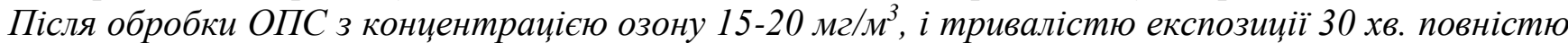
знишуються пліснява, дріжджі, мезофільні аеробні і факультативно анаеробні мікроорганізми.

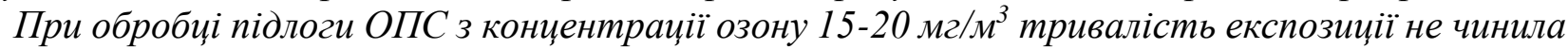
суттєвого впливу на якість дезінфекиіі. Як кількість плісняви та дріжджів так $і$ кількість мезофільних аеробних і факультативно анаеробних мікроорганізмів у дослідних зразках змивів підлоги зменшилася на 99,99\% $(p \leq 0,01)$ у порівнянні з контрольними зразками.

При порівнянні обробки вольєру хлорвмісними засобами та озоно-повітряною сумішшю, було встановлено, щуо одна з основних неприємних властивостей хлору полягала в тому, щуо при його реакиї з більшістю органічних сполук виникав цілий спектр хлорорганічних похідних, більшість із яких дуже отруйні, причому дія циих токсинів полягає в руйнуванні імунної системи як людини так і тварини.
\end{abstract}

Ключові слова: собака, павільйон, озоно-повітряна суміш, обсіменіння, пліснява, КМАФАнМ.

Вступ. Всі живі істоти вимагають для свого життя певних умов середовища, пристосованість до яких виробляється в ході їх історичного та індивідуального розвитку. Середовище, в якому живе собака, різноманітна і мінлива. Умови зовнішнього середовища впливають на собаку і викликають з ії боку ті чи інші дії у відповідь, біологічний сенс яких адаптувати організм собаки до даних умов.

Однак пристосовність собаки до змінних умов середовища не безмежна, а обмежена рамками гомеостазу організму. зміни умов середовища, що виходять за межі цієї пристосовності, особливо якщо вони наступили різко і раптово, порушують життєдіяльність собаки і можуть привести не тільки до хвороби, а й до загибелі [5].

Питання до умов утримання, годівлі, виховання, дресури, профілактики інфекційних хвороб були й залишаються актуальними в собаківництві. Доказом може служити велика кількість вітчизняних і зарубіжних учених, які займаються дослідженнями в даній галузі науки. На жаль, в Україні недостатню увагу приділяють вчені вивченню та покращенню технології утримання собак у розплідниках відомчих установ, де використовуються службові собаки [3]. На організм собаки, ii здоров'я і працездатність впливають фізичні, хімічні, біологічні фактори навколишнього середовища.

Собака, потребує певних умов навколишнього середовища. Умови зовнішнього середовища впливають на собаку, викликаючи з їі боку різні відповідні реакції. Біологічний сенс цих реакцій полягає в тому, щоб пристосувати організм тварини до даних умов існування. Але пристосовність організму до умов зовнішнього середовища - обмежена. Зміни середовища, що виходять за межі пристосовності, особливо якщо вони настали раптово, порушують фізіологічні процеси у собаки і можуть викликати у неї захворювання $[4,6]$.

Дотримання основних правил гігієни є найкращим способом попередження здебільшого неприємностей. На першому етапі виконання роботи необхідно засвоїти загальні принципи 
прибирання та дезінфекції, а на другому - навчитися вибирати найбільш ефективні засоби для цих цілей [1].

Метою наших досліджень було встановити ефективність використання озоно-повітряної суміші для поліпшення санітарно-гігієнічного стану павільйону для утримання собак.

Матеріал та методи досліджень. Дослідження проводилася в умовах навчальнодресирувального центру «Компаньйон» м. Одеса.

Для визначення дії озонатора, щодо санітарно-гігієнічної обробки приміщення для утримання собак, нами були проведені дослідження у вольєрі.

В якості джерела озону використовували озоногенератор «Источник-2 агро М», виготовлений ТОВ «Монтаж-Сервіс-2004» (м. Запоріжжя). Концентрацію озону визначали за допомогою вимірювача «Бозон-ДФГ».

Відбір проб для санітарно-мікробіологічного дослідження предметів ужитку і устаткування проводили за допомогою змивів і відбитків.

Результати досліджень. На початок досліджень санітарна обробка вольєру здійснювалась за допомогою гарячого розчину «Хлорантоін» (дезінфекційний засіб з миючим ефектом ).

Після задовільної оцінки візуального контролю приступали до взяття змивів для бактеріологічних досліджень згідно методики.

Собаки породи німецької вівчарки у НДЦ «Компаньйон» на груповому утриманні.

При груповому утриманні для собак побудовані спеціальні приміщення - павільйони, розділені на кабіни, до яких примикають невеликі, відкриті зверху вигули (вольєри). Для кожної дорослої собаки виділена окрема кабіна з вольєром. Павільйон побудований на 5 собак.

Вигул має рівну бетоновану поверхню, дощатий настил біля будки та каналізаційний стік для сечі та екскрементів.

Для будівництва кабін використали сухе дерево. Кабіна збудована довжиною 2 м, шириною 1,5 м, висота передньої стінки - 2,5 м, задньої - 1,5-2 м. Висота дверей кабіни - 1,7 м, ширина 0,7 м. Двері відкриваються назовні. Над дверима засклена рама для доступу в кабіну світла. У нижній частині дверей кабіни є лаз розміром $40 \times 50$ см, який виходить в вольєр. Влітку лаз тримається відкритим, взимку закривається фіранкою з брезенту або щільної мішковини.

У кожній кабіні дерев'яна розбірна будка довжиною 1 м, шириною 0,9 м і висотою 0,8 м. Розмір лазу такий же, як і в кабіні (40×50 см). Дах будки плоский і знімний. Влітку собаки частіше лежать на даху будки.

На фізіологічний стан організму собаки істотний вплив роблять умови навколишнього середовища. Собаки утримуються в умовах, максимально наближених до природних: основні параметри мікроклімату відповідають показанням відкритого повітря. Однак для них, як і для інших видів тварин, існують певні оптимальні параметри навколишнього середовища, в яких собаки найбільш комфортно себе почувають.

Встановлено, що несприятливий мікроклімат є основною причиною зниження (на 20-30\%) продуктивності тварин, перевитрати (на 15-40\%) кормів, зниження (на 10-30\%) відтворювальної здатності, збільшення кількості захворювань і випадків летального результату (на 15-35\%) у молодняку. Стан мікроклімату в розпліднику можна вважати ідеальним при відсутності запахів і протягу $[2,7]$.

Необхідні параметри мікроклімату, чистоту в приміщеннях для утримання собак і здоров'я тварин можливо підтримувати лише при створенні ефективних і надійних заходів санітарії.

Завдяки постійній підтримці в центрі санітарного стану, допомагає боротися з бактеріями, вірусами, цвіллю, паразитами, загрозами станом здоров'я собак, якості кормових продуктів, питної води і самій будівлі.

Даний метод є альтернативою застосуванню фізичних і хімічних методів дезінфекції.

Озонування - спосіб обробки повітря або води шляхом впливу на них озону 3 метою знезараження і дезодорації. Озонування є ефективним способом очищення повітря від бактерій, в тому числі від їх спорових форм, цвілевих і дріжджових грибів.

Метод озонування має ряд переваг перед хімічними і фізичними методами дезінфекції: озон має бактерицидну і віруліцидні дією сильніше, ніж хлор і інші сильні окислювачі. 
Даний метод є потужним засобом профілактики і боротьби з поширенням туберкульозу, зменшенням числа мікроорганізмів (загального мікробного числа), також озон зменшує число цвілевих і дріжджових грибів [1].

На підставі проведених досліджень експериментально було встановлено, що вже через три цикли неефективних дезінфекційних обробок формується мікрофлора досить стійка до застосовуваних раніше дезінфікуючих засобів, відбувається формування полірезистентних штамів мікроорганізмів. Такі мікробні популяції певним чином відрізняються від батьківських мікроорганізмів за морфологічними, біологічними та іншими ознаками. В результаті ефективність раніше застосовуваних засобів нівелюється.

При порівнянні обробки вольєру хлорвмісними засобами та озоно-повітряною сумішшю, було встановлено, що одна з основних неприємних властивостей хлору полягала в тому, що при його реакції з більшістю органічних сполук виникав цілий спектр хлорорганічних похідних, більшість із яких дуже отруйні, наприклад, хлорфеноли та поліхлорфеноли, особливо, так звані діоксини, що є одними 3 найвідоміших на теперішній час органічних отрут, причому дія цих токсинів полягає в руйнуванні імунної системи як людини так і тварини.

Хлор дуже легко взаємодіє з аміаком, утворюючи хлораміни. Ці речовини володіють дуже слабкою дезінфікуючою дією, але надзвичайно сильно подразнюють слизові оболонки очей і носоглотки.

Хлораміни часто називають «зв'язаним хлором». Цей зв'язаний хлор у 5-10 разів сильніший подразник, ніж вільний хлор.

При оцінці початкового санітарного стану приміщення для утримання собак установлено, що забрудненість майже всіх ділянок перевищувала допустиму норму.

При обробці озоно-повітряною сумішшю приміщення, вихід озонатора направляли у кабіну, а на вхід подавалося повітря.

Результати визначення бактеріального обсіменіння поверхонь після обробки розчином препарату «Хлорантоін» (дезінфекційний засіб з миючим ефектом ) (К) і дезінфекція ОПС 3 концентрацією озону 15 і 18 мг/л після обробки миючим препаратом (Д-1 і Д-2) наведені в табл. 1.

Таблиця 1. Бактеріальне обсіменіння приміщення для собак, КМАФАнМ, КУО/см², $(\mathbf{M} \pm \mathbf{m}, \mathbf{n}=\mathbf{3})$

\begin{tabular}{|l|c|c|c|}
\hline $\begin{array}{c}\text { Місце взяття } \\
\text { проби }\end{array}$ & \multicolumn{1}{|c|}{ К } & Д-1 & Д-2 \\
\hline Стіни & $2,1 \cdot 10^{10} \pm 0,14 \cdot 10^{10}$ & $1,8 \cdot 10^{8} \pm 0,122 \cdot 10^{8}$ & $2,4 \cdot 10^{7} \pm 0,197 \cdot 10^{7 * *}$ \\
\hline Підлога & $8,2 \cdot 10^{12} \pm 0,19 \cdot 10^{12}$ & $6,3 \cdot 10^{10} \pm 0,25 \cdot 10^{10} *$ & $6,0 \cdot 10^{9} \pm 0,19 \cdot 10^{9} * *$ \\
\hline
\end{tabular}

Примітка: * - $\mathrm{p} \leq 0,05 ; * *$ - $\mathrm{p} \leq 0,01$ порівняно з контролем

Порівняно $з$ контролем, обробка елементів приміщення ОПС з концентрацією озону 15 мг/л забезпечує більш якісне знешкодження мікроорганізмів. Вміст КМАФАнМ на внутрішній стіні був меншим на 99,14 \%, а підлоги на - 99,23\% у порівнянні зі зразками контролю. Дія озону в концентрації 18 мг/л ОПС забезпечила ще краще знешкодження бактерій: їх вміст у змивах 3 поверхні стін становив $2,4 \cdot 10^{7} \pm 0,197 \cdot 10^{7} \mathrm{KУО} / \mathrm{cm}^{2}$, а підлоги $-6,0 \cdot 10^{9} \pm 0,19 \cdot 10^{9} \mathrm{KУO} / \mathrm{cm}^{2}$.

Дослідження щодо визначення санітарно-гігієнічної оцінки повітря кабінки за двома мікробіологічними показниками: загальним бактеріальним обсіменінням і вмістом плісняви та дріжджів. Повітря вважається чистим, якщо не перевищує $15000 \mathrm{KУO} / \mathrm{m}^{3}$, а плісняви та дріжджів не більше 25 в $1 \mathrm{~m}^{3}$.

Для зниження бактеріального обсіменіння повітря у вольєрі проводили вологе прибирання. Знизити вміст мікроорганізмів у повітрі можна також, застосовуючи фізичні та хімічні методи знезараження повітря, наприклад. Найефективнішим способом знезараження повітря є його озонування. Озон окислює шкідливі речовини й знищує значну частину бактерій, які знаходяться в атмосфері, саме тому повітря стає безпечним.

Впродовж деякого часу, залишкові молекули озону - розпадаються, перетворюючись у кисень. При цьому вивільняються корисні для здоров'я легкі негативні іони. Які пригнічують позитивні іони, що випромінюються патогенними зонами. 
Результати мікробіологічного дослідження повітря в залежності використаних дезінфектантів представлені в табл. 2.

Таблиця 2. Стан мікробного забруднення повітря за дії хімічних мийно-дезінфікуючого засобу і ОПС, $(\mathbf{n}=3, M \pm m)$

\begin{tabular}{|c|c|c|c|c|}
\hline Показники & $\begin{array}{c}\text { Контроль } \\
\text { плісняви та } \\
\text { дріжджів, см³ }\end{array}$ & 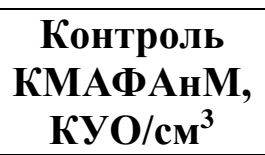 & $\begin{array}{c}\text { Після обробки } \\
\text { плісняви та } \\
\text { дріжджів, см }\end{array}$ & 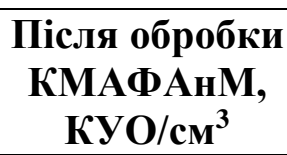 \\
\hline Контроль & $50 \pm 1,88$ & $58500 \pm 11,81$ & $25 \pm 1,41 * * *$ & $39000 \pm 7,07 * *$ \\
\hline ОПС 1 & $50 \pm 3,8$ & $58000 \pm 9,75$ & $22 \pm 3,78$ & $21600 \pm 11,88^{* *}$ \\
\hline ОПС 2 & $45 \pm 1,78$ & $50085 \pm 37,87$ & $15 \pm 1,78$ & $11250 \pm 15,41 *$ \\
\hline ОПС 3 & $48 \pm 2,55$ & $46030 \pm 15,41$ & - & - \\
\hline
\end{tabular}

Примітка: $*$ - $\mathrm{p} \leq 0,05 ; * *-\mathrm{p} \leq 0,01 ; * * *-\mathrm{p} \leq 0,001$ порівняно 3 контролем.

Аналіз даних таблиці вказує на відносно добру ефективність обробки повітря кабінки синтетичним миючим засобом. Так, результати мікробіологічного дослідження повітря, обробленого мийно-дезінфікуючим засобом «Хлорантоін», фіксують зменшення кількості колоній плісняви та дріжджів у двічі, при цьому різниця між контрольними та дослідними зразками була статистично вірогідна ( $\mathrm{p} \leq 0,001)$; кількість мезофільних аеробних і факультативно анаеробних мікроорганізмів у дослідних зразках (після обробки «Хлорантоін») скоротилася на $52,14 \%(\mathrm{p} \leq 0,01)$.

Обробка повітря кабінки озоно-повітряною сумішшю з низькою концентрацією озону (5-10 мг $/ \mathrm{m}^{3}$ ) майже не ефективна по відношенню до мезофільних аеробних і факультативно анаеробних мікроорганізмів. Після такої обробки їх кількість скорочується лише 62,8 \%, така обробка відображається на зменшенні колоній плісняви та дріжджів на 56 \%. При витримці 30 хв. (ОПС 2) колоній плісняви та дріжджів зменшилось на 96,7\%, тоді як КМАФАнМ - на 77,5 \% (p $\leq 0,05)$.

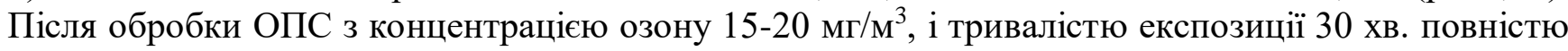
знищуються пліснява, дріжджі, мезофільні аеробні і факультативно анаеробні мікроорганізми.

Стан мікробного забруднення підлоги кабінки за дії мийно-дезінфікуючого засобу та озоноповітряної суміші представлені у табл. 3 .

Як показав аналіз результатів мікробіологічних досліджень змивів, найкращий ефект для дезінфекції підлоги дає використання озоно-повітряної суміші. При концентрації озону 5-10 мг/м ${ }^{3}$ на протязі 30 хв. (ОПС 1) кількість колоній плісняви та дріжджів скорочується на 95,5\% ( $\mathrm{p} \leq 0,01)$, а мезофільні аеробні і факультативно анаеробні мікроорганізми - на 96,2 \% (p $\leq 0,01)$.

Таблиця 3. Стан мікробного забруднення підлоги кабінки за дії хімічного мийнодезінфікуючого засобу і ОПС, $(\mathrm{n}=3, \mathrm{M} \pm \mathrm{m})$

\begin{tabular}{|c|c|c|c|c|}
\hline Пок & 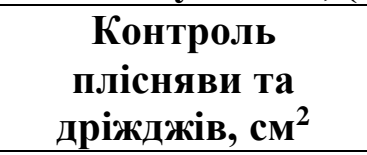 & $\begin{array}{c}\text { Контроль } \\
\text { КМАФАнМ, } \\
\text { КУО/см } \\
\end{array}$ & $\begin{array}{c}\text { Після обробки } \\
\text { плісняви та } \\
\text { дріжджів, см² }\end{array}$ & $\begin{array}{c}\text { Після обробки } \\
\text { КМАФАнМ, } \\
\text { КУО/см² } \\
\end{array}$ \\
\hline Контроль & $7,7 \cdot 10^{15} \pm 0,187 \cdot 10^{15}$ & $6,2 \cdot 10^{17} \pm 0,19 \cdot 10^{17}$ & $8,4 \cdot 10^{14} \pm 0,19 \cdot 10^{14}$ & $1,8 \cdot 10^{16} \pm 0,25 \cdot 10^{16 * *}$ \\
\hline ОПС 1 & $8,5 \cdot 10^{15} \pm 0,19 \cdot 10^{15}$ & $6,0 \cdot 10^{17} \pm 0,19 \cdot 10^{17}$ & $3,8 \cdot 10^{14} \pm 0,14 \cdot 10^{14} * *$ & $2,3 \cdot 10^{16} \pm 0,25 \cdot 10^{16 * *}$ \\
\hline ОПС 2 & $2,7 \cdot 10^{15} \pm 0,19 \cdot 10^{15}$ & $5,1 \cdot 10^{17} \pm 0,21 \cdot 10^{17}$ & $8,6 \cdot 10^{13} \pm 0,25 \cdot 10^{13 *}$ & $6,3 \cdot 10^{13} \pm 0,19 \cdot 10^{13}$ \\
\hline ОПС 3 & $9,6 \cdot 10^{15} \pm 0,28 \cdot 10^{15}$ & $5,2 \cdot 10^{17} \pm 0,19 \cdot 10^{17}$ & $1,0 \cdot 10^{12} \pm 0,28 \cdot 10^{12} * *$ & $1,3 \cdot 10^{13} \pm 0,14 \cdot 10^{13 * *}$ \\
\hline
\end{tabular}

Примітка: * - $\mathrm{p} \leq 0,05 ; * *-\mathrm{p} \leq 0,01$ порівняно з контролем

За умови підвищення концентрації озону в озоно-повітряній суміші до 10-15 мг/м³ (ОПС 2) кількість плісняви та дріжджів у дослідних зразках зменшилась на 95,9 \% (p $\leq 0,05)$, а КМАФАнМ

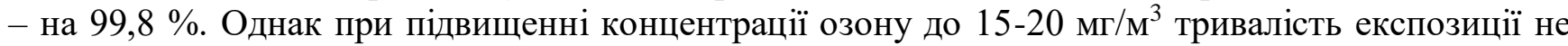
чинила суттєвого впливу на якість дезінфекції. Як кількість плісняви та дріжджів так і кількість мезофільних аеробних і факультативно анаеробних мікроорганізмів у дослідних зразках змивів підлоги зменшилася на 99,99\% ( $\leq$ 0,01) у порівнянні з контрольними зразками.

Висновки. Озоно-повітряна суміш $\epsilon$ ефективним способом знезараження приміщення та дезінфекції повітря, ступінь якого залежить від концентрації озону і тривалості експозиції. Після 
обробки ОПС $з$ концентрацією озону 15-20 мг/м³, і тривалістю експозиції 30 хв. повністю знищуються пліснява, дріжджі, мезофільні аеробні і факультативно анаеробні мікроорганізми у повітрі.

Стан мікробного забруднення підлоги кабінки за дії озоно-повітряної суміші 3 концентрацією озону 15-20 мг/м³ покращився на 99,99\%.

\section{Список використаних джерел}

1. Антоненко П.П., Пушкар Т.Д. Озонування виробничих приміщень на підприємствах молочної промисловості Науково-технічний бюлетень НДЦ «Біобезпека та екологічний контроль ресурсів АПК» Т. 2. №3. Дніпропетровськ, 2014. С. 143-146.

2. Королев Б. А. Техногенные воздействия на физиологию животных. Тюмень, 2000. 134 c.

3. Маневич Б. В. Косьяненко Т. В. О регламентации и применении дезинфекционных средств, в том числе с моющим действием. Молочная промышленность. 2009. № 11. С. 6-9.

4. Стаєнний О. В. Розвиток поведінки собак та періоди чутливості / О. В. Стаєнний. Науковий вісник Львівської національної академії ветеринарної медицини імені С. 3. Гжицького. Львів, 2007. Т. 9. № 1 (32). С. 384-388.

5. Садыкова Ю.Р. Морфофункциональное состояние крови и мочевыделительной системы собак служебного назначения в зависимости от условий содержания и эксплуатации. Автореф. дис. канд. биол. наук. Казань, 2008. 26 с.

6. Шалабот Н.Е. Некоторые новые данные к заболеванию собак и щенков в войсковых питомниках пограничных войск. Клуб служебного собаководства. Москва, 1991. С. 157-168.

7. Awad M. B., Castle G. S. Somme parameters affecting the generation of ozone in positive and negative corona. IEEE-IAS. New-York, 1983. P. 373-380.

\section{ИССЛЕДОВАНИЕ ВЛИЯНИЯ РЕЖИМОВ САНИТАРНО-ГИГИЕНИЧЕСКОЙ ОБРАБОТКИ ПАВИЛЬОНУ ДЛЯ СОДЕРЖАНИЯ СОБАК}

\section{Пушкарь Т., Гурко,Е. Хамид К.}

Проведено исследование санитарной обработки помещения для содержания собак различными дезинфектанты. Показана перспективность озоновых технологий для дезинфекиии павильона.

Санитарная обработка вольер осуществлялась $c$ помощью горячего раствора «Хлорантоин» (дезинфищирующее средство с моющим эфффектом). При оценке начального санитарного состояния помещения для содержания собак установлено, что загрязненность многих участков превышала допустимую норму.

Доказано, что озоно-воздушная смесь является эффективным способом обеззараживания помещуения и дезинфекции воздуха, степень которого зависит от концентрации озона $u$ продолжительности экспозищии. После обработки ОВС с кониентрацией озона 15-20 мг / ${ }^{3}, u$ продолжительностью экспозиции 30 мин. полностью уничтожаются плесень, дрожжи, мезофильные аэробные и факультативно анаэробные микроорганизмы.

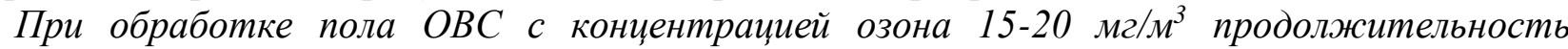
экспозиции не оказывала существенного влияния на качество дезинфекции. Как количество плесени и дрожжей так и количество мезофильных аэробных и факультативно анаэробных микроорганизмов в опытных образиах смывов пола уменьшилась на 99,99\% ( $\leq$ 0,01) по сравнению с контрольными образиами.

При сравнении обработки вольер хлорсодержащими средствами и озоно-воздушной смесью, было установлено, что одна из основных неприятных свойств хлора заключалась в том, что при его реакции с большинством органических соединений возникал иельй спектр хлорорганических производных, большинство из которых очень ядовиты, причем действие этих токсинов заключается в разрушении иммунной системы как человека так и животные.

Ключевые слова: собака, павильон, озоно-воздушная смесь, обсеменение, плесень, КМАФАнМ. 


\section{STUDY OF THE INFLUENCE OF THE REGIMES OF SANITARY AND HYGIENIC TREATMENT OF THE PAVILION FOR KEEPING DOGS}

Pushkar T., Gurko E. , Khamid K.

A study was conducted on the sanitation of the room for keeping dogs with various disinfectants. The prospects of ozone technologies for disinfection of the pavilion are shown.

Sanitary treatment of the aviary was carried out using a hot solution "Chlorantoin" (disinfectant with detergent effect). When assessing the initial sanitary condition of the room for keeping dogs, it was found that the contamination of almost all areas exceeded the permissible norm.

It has been proven that the ozone-air mixture is an effective way to disinfect the room and disinfect the air, the degree of which depends on the concentration of ozone and the duration of exposure. After treatment with OAM with an ozone concentration of 15-20 $\mathrm{mg} / \mathrm{m}^{3}$, and an exposure duration of 30 minutes mold, yeast, mesophilic aerobic and optionally anaerobic microorganisms are completely destroyed.

When treating the floor OAM with an ozone concentration of $15-20 \mathrm{mg}^{\prime} \mathrm{m}^{3}$, the duration of exposure did not have a significant effect on the quality of disinfection. Both the amount of mold and yeast and the number of mesophilic aerobic and optionally anaerobic microorganisms in the experimental samples of floor washes decreased by $99.99 \%(p \leq 0.01)$ compared with control samples.

When comparing the treatment of the enclosure with chlorine-containing agents and ozone-air mixture, it was found that one of the main unpleasant properties of chlorine was that when it reacted with most organic compounds there was a range of organochlorine derivatives, most of which are very toxic, and the action of these toxins is to destroy the immune system of both humans and animals.

Key words: dog, pavilion, ozone-air mixture, contamination, mold, the number of mesophilic aerobic and optionally anaerobic microorganisms. 